\title{
Oil Exploitation and Constitutional Protection of the Environment in Chad
}

\author{
Didegomi Dar \\ PhD student in Public Law at the Faculty of Law and Political Science \\ University of Ngaoundéré, Cameroon \\ Email: demmanueldidegomi [AT] gmail.com
}

\begin{abstract}
The study on oil exploitation and constitutional protection of the environment in Chad aims to show that despite the constitutional consideration of fundamental rights to the environment, environmental protection remains problematic. This is because the constitutional texts of protections are often ambiguous, incomplete, scattered and derisory. Also, the fact that environmental law is part of the rights-claims which in general are only addressed to the attention of the public authorities, poses a real problem as to its justice. Therefore, the right to the environment does not enjoy the same degree of jurisdictional protection as other rights. As a result, they often have no direct effect. Thus, in the oil exploitation framework, the environmental protection offered by the Chadian constitution, could only be insufficient except recourse to the activation of the ordinary ways of right.
\end{abstract}

Keywords---- Oil exploitation, Chad, Environment, Right

\section{INTRODUCTION}

The issue of protecting human rights to a healthy environment in the context of oil exploitation remains a topical issue in the doctrine ${ }^{1}$ as well as among practitioners, human rights defenders and multinationals.

Indeed, the exploitation of natural resources in general and oil in particular is often a source of human rights violations in general and environmental ones in particular. Through Ecuador, the Niger Delta and Chernobyl, ecological disasters resulting from the exploitation of natural resources is well established.

With this recognition, ecological crimes around the world and often caused by the exploitation of natural resources, there has been an "ecological conscience" at the international level ${ }^{2}$. It is therefore, what justified the holding of the international conferences with a view to controlling if not frame this phenomenon with a view to an environmental protection and indirectly of the man within the framework of the extractive industries. These conferences have laid the foundations for declarations, conventions and principles relating to environmental protection, a guarantee of sustainable development.

Internally, this has resulted in the internalization or the constitutionalisation of certain environmental standards. Chad, in fact, has not remained on the side-lines of this "green constitutionalism" which is now in vogue in most constitutions.

Only, one could question what is an oil exploitation and constitutional protection of the environment.

Literally, exploitation is the act of exploiting and developing for profit ${ }^{3}$. In the context of this work, "exploitation" is understood to mean studies and works, in particular drilling and completion of wells as well as the construction of necessary facilities, with a view to developing and putting into production a hydrocarbon deposit. , the operations of the first preparation of the hydrocarbons produced, with the aim of making them commercial, the transport of these hydrocarbons, in particular by channelling, their marketing and more generally all other operations related to the previous ones and contributing to the same objectives ${ }^{4}$.

\footnotetext{
${ }^{1}$ BURGORGUE-LARSEN (L), « La protection constitutionnelle de l'environnement en droit comparé », Environnement et Développement durable, ${ }^{\circ} 12$, décembre 2012, dossier 30, pp.1-30 ; RANDRIANANDRASANA (I), « La protection constitutionnelle de l'environnement à Madagascar, Revue juridique de l'environnement, 2016/1, vol.41, pp 122-139 ; HAUMONT (F), "Le droit constitutionnel belge à la protection d'un environnement sain. Etat de la Jurisprudence »; Revue juridique de l'environnement, 2005, $\mathrm{n}^{\circ}$ spécial, pp.41-52 Etc.

${ }^{2}$ United Nations Conference on the Environment held in Stockholm from 5 to 16 June 1972; United Nations Conference on Environment and Light Development in Rio de Janeiro from 3 to 14 June 1992 etc.

3 Definition given by Larousse 2010.

${ }^{4}$ Law No. 07-006 of 2 May 2007 on hydrocarbons in Chad. According to the Cameroonian Petroleum Code, exploitation is defined as "operations to extract Hydrocarbons for commercial purposes, including development and production operations and related activities such as the abandonment of wells and hydrocarbon deposits. "
} 
As for oil, it comes from the Latin "petra" which means stone and "oleum" oil, or "stone oil" 5 , is a liquid carbon rock, or mineral oil. Oil is a complex mixture of liquid hydrocarbons that form naturally in groundwater. It is a brown, viscous liquid that is buried underground or at the bottom of the sea, contains hydrocarbons and is a major source of energy 6 .

As for the protection, it comes from the verb "to protect" which means to shelter from danger, from an incident ${ }^{7}$. It's the act of protecting, defending someone, something ${ }^{8}$. According to Innocent BIRUKA ${ }^{9}$, the basic concept of protection comes from the Latin word "pro-tegere" meaning literally "cover forward". According to the legal vocabulary of Gerard Cornu, protection means precaution which, responding to the need of the one or that it covers and generally corresponding to a duty for the one who insures it, is to protect a person or a property against a risk, to guarantee its security its integrity etc., by legal or material means ${ }^{10}$; likewise, this term refers both to the action to protect and the system of protection established. The notion of "protection" thus underlies a screen, an umbrella or a shield that is interposed between a person and / or a property in danger. The lexical field of the concept of protection therefore evokes the idea of securing, safeguard, guarantee, help, envelope, cover, insurance, apron screen and mask ${ }^{11}$.

With regard to the environment, it is defined by decree 10-630 2010-08-04 PR / PM / MERH regulating environmental impact studies in the Republic of Chad in its article 2, as " all natural and artificial elements that promote the existence, evolution and development of the environment, living organisms and human activities while respecting the ecological balance ".

Thus, the constitutional protection of the environment in the exploitation framework assumes a guarantee that the fundamental norm is supposed to be given to the fundamental rights to the environment to avoid that the oil exploitation is a source of ecological catastrophe or violation of the fundamental rights to the environment.

Unfortunately, although constitutionalised, fundamental rights to the environment are often violated. Recognizing that the exploitation of oil is often the source of the natural disaster causing violations of fundamental rights, the choice of such a theme proves to be justified in more than one way. Of these drifts often due to the normative weakness, of which at the top is the constitution, our contribution is first of all critical by scrutinizing the fundamental norm in order to highlight the flaws that could lead to the risk of violation of the fundamental rights. Once these flaws identified, it is necessary to propose solutions for a better protection of fundamental rights in the context of oil exploitation. This demonstrates the value of such a study.

Thus, our study based on Chad under the legal prism, in the era known as "democratic"12 and oil exploitation ${ }^{13}$, is not exhaustive; because we will be called from time to time to make a detour in comparative law to apprehend the level of protection by the yardstick of that elsewhere.

While there is no doubt that the consideration of environmental protection in most constitutions generating the concept of "green constitutionalism", it must be admitted that this consecration is often symbolic. The analysis of the national and international field shows that the right to the environment is one of the so-called rights-claims, especially in the category of "economic and social rights" which in general is only for the attention public authorities ${ }^{14}$ and their realization often requires their intervention.

Thus, the concern is how does the Chadian constitution protect the fundamental rights to the environment in oil exploitation?

To answer this central question we make the following assumption: the constitutional protection of fundamental rights in the oil exploitation framework in Chad remains insufficient.

\footnotetext{
${ }^{5}$ Voir Réveillez- vous - 8 novembre 2003, p.3.

${ }^{6}$ Microsoft Encarta 2009.

${ }^{7}$ Dictionnaire Petit Larousse Illustré, 2012, pp.1057-1058.

${ }^{8}$ Le Petit Larousse 2013 précité.

${ }^{9}$ BIRUKA (I), La protection de la femme et de l'enfant dans les conflits armés en Afrique, L'Harmattan, 2006 , p. 27.

${ }^{10}$ Vocabulaire juridique Gerard CORNU, PUF, 9e édition, 2011, p.815.

11 BUGNiON (F), « le Comité international de la Croix-Rouge et la protection des victimes de guerre », in Revue Internationale de la Croix-Rouge, $\mathrm{n}^{\circ} 775$, janvier-février 1985 , p.5.

12 Although with the coming to power of President Déby Itno in 1990, the process of democracy is engaged but remains tainted cases of excesses. What is not enough to talk about democracy as such in Chad.

That is, the period from 1990 to the present day.

13 That is, the period from 1990 to the present day.

${ }^{14}$ BURGORGUE-LARSEN (L), « La protection constitutionnelle de l'environnement en droit comparé », op.cit., p.2.
} 
From the foregoing, our study aims to show that the protection of the environmental rights offered by the Chadian Constitution is less incentive on the one hand (I) and its justiciability remains relative (II).

\section{CONSTITUTIONAL ENVIRONMENTAL PROTECTION LESS INCENTIVE}

The issue of protecting the environment and human rights is taken into account in the Chadian constitution, but in a pithy way and therefore less incentive for better protection. Thus, by going through the Chadian constitution one realizes that it deals in a general way with the right of the environment. At first glance we can congratulate ourselves. But by looking closely at them, it is realized that these provisions cannot effectively protect human rights in the context of oil exploitation, and could leave human rights in an uncertain situation. This is because, in our analysis, these environmental constitutional provisions appear incomplete and are contained in the constitution in a sparse manner, which may not contribute to the strengthening of human rights in the context of oil exploitation.

Thus, we think that this protection offered by the constitutional provisions is less incentive because incomplete (A), scattered and derisory (B).

\section{A- Incomplete environmental constitutional provisions}

While the political will to protect the environment is reflected in the constitutional legal order, it is important to consider the legal scope of the provisions contained in this text.

It must be said that despite taking into account the protection of the environment and therefore human rights in the Chadian constitution, it seems in our humble opinion incomplete. It is incomplete because there are weaknesses in the constitutional provisions that must be reinforced (1) but also the inexistence of the affirmation of the recognition of a right of nature (2) yet recognized in certain constitutions in view of better protection.

\section{1) Constitutional provisions to be strengthened}

Taking into account the environmental issue in recent decades in the constitutions of several states ${ }^{15}$ has led to the birth of the notion of "green" constitutionalism. Constitutionalism "green" therefore requires a sufficient consideration of environmental protection in the constitution. It is not enough just to insert a few words or sentences less complete or that could be confusing as is currently the case in the Chadian constitution, but go beyond. Thus, to speak of "green" constitutionalism in Chad, there are normative efforts to be made, including that of supplementing the existing provisions which, in our view, appear incomplete.

Regarding these incomplete environmental provisions, we should cite the case of article 51 of the constitution of 04 May 2018 which states that "everyone has the right to a healthy environment". This provision would be almost complete if added or supplemented by "ecologically balanced". This would give: "Everyone has the right to a healthy and ecologically balanced environment" which is also a formula that wins the prize of constitutional interest as is the case in Argentina, Bolivia, Brazil, Colombia, Ecuador, Guatemala, Nicaragua, Paraguay and Venezuela. Indeed one can benefit from a right to a healthy environment without the environment being ecologically balanced, which would be a long-term danger for humans. Or, to be clearer, use the formula set out in the 2004 Environmental Charter, which states clearly that "everyone has the right to live in a balanced and healthy environment" ${ }^{16}$. In this provision when we talk about an environment balanced and respectful of health, it's all-encompassing. Indeed, the notion of equilibrium, sometimes used in foreign constitutions, refers to the maintenance of biodiversity, the proper functioning of ecosystems and the control of pollution. The notion of

\footnotetext{
${ }^{15}$ Not to mention all States, we will limit ourselves as an example of some constitutional provisions of African States dealing with the issue : At the internal level, several African countries enshrine in their Constitution, the right to the environment. Thus, in Benin, Article 27 of Law No. 90-32 of 11 December 1990 on the Constitution of the Republic of Benin provides that: "Everyone has the right to a healthy, satisfying and sustainable environment and has the right to defend. The state takes care of the protection of the environment. In Burkina Faso, Article 29 of the Constitution (adopted by referendum on 2 June 1991 and revised) provides: "The right to a healthy environment is recognized; the protection, defense and promotion of the environment is a duty for all. ". In Mali, through paragraph 5 of the Preamble of the Malian Constitution of 25 February 1992, the sovereign people of Mali are committed to improving the quality of life, protecting the environment and cultural heritage . Article 15 adds: "Everyone has the right to a healthy environment. Protection, the protection of the environment and the promotion of the quality of life are a duty for all and for the State ". In Côte d'Ivoire, Article 19 of Law No. 2000-513 of 1 August 2000 on the Constitution of Côte d'Ivoire states that "The right to a healthy environment is recognized for everyone. ". In Togo, Article 41 of the Constitution (adopted by Referendum on 27 September 1992 and amended) provides that: "Everyone has the right to a healthy environment. The state takes care of the protection of the environment. "
}

\footnotetext{
${ }^{16}$ Article 01 of the Environmental Charter.
} 
a balanced environment implies taking into account factors whose list remains open. Balance between the different elements that make up nature (animals, man, plants, natural elements, breeding activities and wild fauna ...). But also a balance between the protection of the environment and the requirements of economic development and social progress ${ }^{17}$. Regarding the second aspect, it establishes the classical link between environment and health, its formulation bringing it closer to the idea of a healthy environment that is often used to qualify this right ${ }^{18}$. Thus, it is understandable that the Chadian constitution stating that "everyone has the right to a healthy environment" seems to be limited when the healthy environment refers to the health aspect and does not affect the notion of balance that refers to maintenance of biodiversity, the functioning of ecosystems and the control of pollution. This consideration of environmental concerns therefore appears to be restrictive and should be supplemented for effective constitutional protection.

It must be said that this is the healthy or balanced environment formula, the contours seem to be less determined. This finding of indeterminacy of the relative constitutional provisions could constitute a risk within the framework of protection of human rights to the environment.

Also, we do not find in this constitution requirements such as environmental impact ${ }^{19}$ assessment organization, environmental damage and the related reparation ${ }^{20}$ and even environmental education. The Chadian constitution does not enshrine a provision dealing, for example, with the right of access to environmental information and the right to participate, as is the case in France ${ }^{21}$. This underscores the unenthusiastic nature of the Chadian Constitution in the context of the protection of human rights in the context of the exploitation of national natural resources in general and oil in particular.

Thus, it is clear that for a better consideration therefore of a better protection of the environment and thus of the human rights, it is necessary to strengthen its constitutional provisions in order to make them complete, thus more protective of the environment. To this limit is added that of the inexistence of a constitutional affirmation of a right of nature.

\section{(2) The non-existence of a right inherent in nature}

With "green constitutionalism," it should be remembered, most constitutions incorporate environmental concerns by going beyond the recognition of a right to a healthy environment. At first sight, the Malagasy constitution seems avantgarde in the matter. From its original version, in 1959, it had provisions relating to the preservation of natural resources and the environment ${ }^{22}$.

In addition to the recognition of environmental law in constitutions, there is an increasing tendency to constitutional consecration of a natural right today.

However, on reading the Chadian constitution, she nowhere mentions that nature as such is right; whereas, with a view to better constitutional protection of the environment, as is the case in Ecuador ${ }^{23}$, a constitutional provision must be enshrined which must proclaim loudly and clearly that "nature as such is right". It should therefore be remembered that "man conceives his identity in the elements of his natural environment" and that "man belongs to the natural environment that surrounds him" 24 . We understand here that we must go beyond a right to an environment to refer to the field of natural resources. Thus, the existence of nature must be respected as its maintenance and the regeneration of its life cycles. This reflects the respect for nature inspired by intergenerational solidarity. This is to say here that all generations must transmit to future generations a nature in good working order able to ensure a dignified life. It is perhaps the absence of such a constitutional provision that has resulted in the elimination of $10 \%$ of oil revenues for the future generation by the Government and an oil exploitation "abusive" and poorly managed without worrying about this future generation, while the victim of the natural calamities of tomorrow, is the future generation. However, "a generation cannot subject future generations to legal standards that are less protective of the environment than those in force" 25 . This being the case, it is the duty of the public authorities not to make regress the protection of the environment. So we could say that this is a constitutional protection that ignores the rights of future generations in oil production. This is a void that the Chadian

\footnotetext{
17 Voir MATHIEU (B.), « La constitutionnalisation du droit de l'environnement : La Charte adossée à la Constitution française », Xe Journées juridiques franco-chinoises, Paris 11-19 octobre 2006.

${ }^{18}$ Dictionnaire des Droits de l'Homme, PUF, p.374.

${ }^{19}$ As it is the case in Brazil, Ecuador and Venezuela

${ }^{20}$ As it is the case in Argentina, Bolivia, Brazil, Colombia, Ecuador and Paraguay

${ }^{21}$ Article 7 of the Environmental Charter in France

22 IANJATIANA (R.), « La protection constitutionnelle de l'environnement au Madagascar », Revue Juridique de l'Environnement, 2016, vol pp. $\neg 122-139$.

${ }^{23}$ The constitution of Ecuador seems to be the only constitution in the world to claim that nature has the right.

${ }^{24}$ Lire PRIEUR (M), « Promesses et réalisations de la Charte de l'environnement », Les Nouveaux Cahiers du Conseil Constitutionnel, 2014/2, n 43 , pp. 5-24.

${ }^{25}$ PRIEUR (M.), « La non régression condition du développement durable » in Révue Vraiment durable, 2013/1, p.177.
} 
constitution should have filled if it is truly an incentive and protector of human rights in general and in the context of the protection of human rights related to oil exploitation in particular.

Unfortunately, in reading the Chadian constitution, it does not enshrine a provision which asserts that nature has a right and this allows us to admit that the present constitutional protection seems incomplete.

On reading the above, it is clear that the constitutional provisions protecting human rights in environmental matters contain a number of shortcomings, if not inadequacies, which it is necessary to complete. In addition to these inadequacies and shortcomings already outlined, these provisions are sparsely contained in the constitution.

\section{B- Sparse and derisory environmental constitutional provisions}

In addition to the incompleteness of the constitutional provisions, thus leaving flaws that could undermine the protection of fundamental rights, it should also be noted that these provisions which concern the fundamental right to a healthy environment are arranged in a sparse manner in the constitution, which may hinder the protection of fundamental rights accessibility, intelligibility.

Thus, it is appropriate to show that the risk remains when the constitutional provisions devoted to the protection of the environment in Chad are, on the one hand, contained sparingly (1) and on the other hand they are derisory (2).

\section{1) Environmental provisions sparsely contained in the constitution}

Looking through the Chadian constitution of May 4, 2018 we realize that provisions that concern the environment are contained sparsely in it. The first constitutional provision dealing with the environment is Article 51, which should be recalled, states that "Everyone has the right to a healthy environment. Article 52 states: "The State and the Autonomous Communities must ensure the protection of the environment". So far the problem does not arise because these provisions follow each other automatically. Unfortunately, it only stops at this level, the third provision is a bit far in Article 57 and states that "The protection of the environment is a duty for all. The State and the Autonomous Communities take care of the defense and the protection of the environment. Any damage to the environment must be properly repaired. We note here that this provision is separated by the first two dealing with the environment of four provisions and that do not even deal with the environmental issue. Also, the last constitutional provision relating to the environment but which does not deal with the protection aspect is found in Article $63^{26}$ concerning the sovereignty of the State over natural resources.

As a result, it can be seen that not all of these environmental protection provisions are in a single title or chapter that deals only with the environment. That which does not contribute to their rapid discovery, and to enumerate them, must go through the whole constitution; This does not make the task easy for a typical citizen who would like to avail himself of a constitutional provision guaranteeing the right to a healthy environment.

For example, we believe that all of these environmental protection provisions that are sparsely contained in the constitution must be brought together in one place, even if it is not in a single chapter dealing with the environment; already that there are four articles in total dealing with the environment so it may well be a whole chapter to promote accessibility and speed in the search for constitutional provisions relating to the environment; which would help to avoid falling foul of the principle of "nemo censetur ignorare legem" 27 . If not as currently arranged, they are scattered, and may not contribute effectively to the rapid understanding of these provisions. You need a title or chapter devoted solely to the environmental issue.

It should also be noted that the accessibility of a text is a guarantee of legal certainty for a citizen. The fact that the constitutional provisions are disparate could be a source of legal uncertainty because one could get lost in wanting to go through the constitutional provisions that concern the environment. Also, the fact that the constitution does not devote sufficient provisions to the environment as they are derisory.

\footnotetext{
26 Article 63 of the aforementioned Chadian Constitution provides that: «L'Etat exerce sa souveraineté entière et permanente sur toutes les richesses et les ressources naturelles nationales pour le bien-être de toute la communauté nationale $\gg$

${ }^{27}$ Latin adage meaning no one is supposed to ignore the law. With regard to this article read AKAM AKAM (A.), « nul n’est censé ignorer la loi », Revue Africaine des Sciences Juridiques, 2007, vol.4, n¹, pp1-19. A ce sujet conclut que la présomption de connaissance de la loi qu'elle édicte n'aurait de sens que si elle s'accompagne d'un effort réel de modernisation et d'intensification des techniques et modalités de la communication de l'information juridique. Cette information doit être accessible et compréhensible.
} 


\section{2) derisory provisions}

In addition to being sparingly contained in the constitution, the provisions that deal with the environmental issue turn out to be derisory in number, which may not cover the entire environmental issue.

Looking through the Chadian constitution, we realize that the provisions dealing with the protection of the environment are very small in number. In fact, there are only three provisions ${ }^{28}$ of this constitution that deal with the environment.

In order to give the environment a special place in the rank of fundamental rights, some countries have made a considerable effort at constitutional enlargement to ensure respect for this fundamental right. In Brazil, for example, about 18 constitutional articles make direct reference to the protection of the environment, and the right to an ecologically balanced environment is recognized by "all" 29 for present and future generations. In France, there is a whole charter of the environment which is backed by the constitution. "This is why the right to the environment falls into the category of diffuse interests and is not limited to one person but concerns a broader set of an indeterminate community". Thus, far from calling into question the relativity of constitutional protection, it must be recognized that every citizen has a subjective right and an interest in acting to defend it not only in the event of personal injury, but also in the event of collective harm. that is to say, even when the person concerned is not touched "directly" in his or her well-being. This is not an absolute guarantee of respect for the law in practice, but at least the standard provides solid instruments to ensure the effectiveness of the subjective right to a healthy environment.

So compared to Brazil which devotes 18 articles and France which devotes a whole charter for environmental protection, the environmental protection offered by the Chadian constitution with only three articles seems derisory. This could justify the lack of enthusiasm that the public authorities give to the environmental issue.

So with a view to effective constitutional protection and to speak of a green constitutionalism in Chad, it is necessary to supplement these constitutional provisions and to bring them together in one place even if it is not in a single chapter and also densify them. In addition to these constitutional limits mentioned are those relating to justiciability.

\section{II- ENVIRONMENTAL CONSTITUTIONAL PROTECTION MARKED BY RELATIVE} JUSTICIABILITY

Even though the Chadian Constitution enshrines certain provisions for the protection of nature, it is important to ask whether an individual can jurisdiction to obtain protection? Or can the right to a healthy environment be invoked to require the state to do its utmost to guarantee it?

As we pointed out above, this right to a healthy environment is part of the category of rights which we call "rights claims" and these rights are understandably only addressed to attention of the governors. A right which is generally addressed to the public authorities and which is formulated in the form of wishes is limited from the point of view of justiciability and therefore of its invocability before a court.

This will lead us to demonstrate that this is a minimum justiciability on the one hand (A) and indirect on the other hand $(\mathrm{B})$.

\section{A- $A$ relativized protection by minimal justiciability}

Accession to constitutionalisation is a general phenomenon as it is clear that the environment has become a major political issue and that, whatever the regimes and sensitivities, its protection requires a consecration at the highest normative level $^{30}$.

The constitutionalization of environmental law offers the justiciable minimum justi fi city, first of all because of its hybrid nature (1) then because of a balance of interests (2).

\footnotetext{
28 These are Articles 51, 52 and 57 of the Constitution.

${ }^{29}$ It must be remembered that the same wording was used by the Portuguese Constitution (« Art. 66-1. Tous ont droit à un environnement sain et écologiquement équilibré... ») et par la Constitution espagnole (« Art. 45 1. Todos tienen el derecho a disfrutar de un medio ambiente adecuado... »). Comme l'explique G. Real Ferrer, cet énoncé a été expressément utilisé par le législateur constitutionnel espagnol pour renforcer le caractère universel du droit en question. Cf. REAL FERRER, G., El medio ambiente en la Constitución española de 1978, p. 321, note 7. Voir aussi : GOMES DA SILVA, J. C., Human rights in the portuguese Constitution. Cité par BURGORGUE-LARSEN (L), « La protection constitutionnelle de l'environnement en droit comparé », op. cit., pp.1-30.

${ }^{30}$ MORAND-DEVILLER (J), « L'environnement dans les constitutions étrangères », Les Nouveaux Cahiers du Conseil Constitutionnel, 2014/2, n 43 pp.83-95
} 


\section{1) The hybrid nature of the right to the environment}

The right to the environment is part of the human rights of the third generation, rights of solidarity that emphasize the bonds of mutual dependence and thus transcend the distinction right-freedom - right-claim. It has a hybrid character.

As an individual's fundamental right, it must be admitted, it is accompanied by certain procedural safeguards such as access to justice to defend it from attacks by public and private persons. But the problem is its hybrid character at the level of right-claim.

Indeed, since a human right is one of the rights that one qualifies as right-claim, its effectiveness is often problematic. The right-claim, as a social right, its realization therefore requires intervention of the state, and it is precisely at this point that the problem arises. These are therefore rights that imply a positive obligation on the part of the State to oppose those who are defensive and who claim abstention above all. These claims rights have a lesser scope to the rights freedoms and this for multiple reasons: difficulty for the judge to punish them in the event of lack of legislative implementation, need to guarantee them to make political arbitrations and budgetary choices under the sole national representation etc. these rights are conditioned by the content that requires the intervention of the legislator, they are rights to public material benefits ${ }^{31}$.

Also, formulated as a subjective right, the right to a healthy environment to an obvious ideological vocation: to maintain in the mind of the citizen that he has a right to obtain protection and repair of the attacks likely to be brought to his environment. So, the temptation will be strong to read this provision as formulating a subjective right. To yield to this temptation would open to everyone the right to take legal action against attacks on their environment, either by the public authorities or by other private persons, especially when their health is threatened. This recognition would lead to a proliferation of litigation, the effectiveness of which remains to be demonstrated. In fact, each court seised should, in order to satisfy the claim of that right, engage in a proportionality test ${ }^{32}$.

This protection suggests to us here that this is a principle that requires public authorities to act or not to act. Having the fullness of territorial sovereignty, the State sometimes behaves in absolute terms with respect to these rights and claims. He does not have the same pressure with other rights, including civil and political rights. Debt entitlements often remain wishful thinking.

Referring to comparative law, we must recognize with Bertrand MATHIEU ${ }^{33}$ that in reality this right is related to a social right which as such falls within the category of constitutional objectives. From this point of view, a parallel could be drawn with the constitutional treatment of the right to the protection of health. In this respect, it should be noted that the draft Constitution for Europe establishes a distinction in terms of fundamental rights between rights and principles, the latter category being comparable to constitutional objectives. From this point of view, the protection of the environment is an objective of the Union (Articles I-3, II-97 and Preamble of the Charter of Fundamental Rights).

Thus, the hybridity of the right to the environment in particular its character of right-claim sometimes makes uncertain its effectiveness thus of minimum justiciability is that could compromise the effective realization of the human rights within the framework of oil exploitation. To the uncertainty of justiciability due to the hybrid nature of the right to the environment is added the technique of balance of interests which further compromises this justiciability.

\section{2) The balance of interest technique}

Justiciability of the right to the environment in the constitutional field is minimal not only because of its hybrid nature but above all because of the balance of interest technique, which often puts it second in relation to other fundamental rights. To say that this justiciability is minimal is to accept in other words that this constitutional environmental protection is not maximal, that it does not reach a high degree of protection, the level of protection proves to be weak and therefore does not does not automatically allow a litigant to rely on it before a court to easily win the case. It is to show here that although constitutionalized, the right to a healthy environment may not fully benefit from the protection mechanisms applicable to others. As an illustration, we can mention the case of Portugal and Spain where we can benefit but with a very low degree of protection.

Indeed, the practice has shown in some countries that the Constitutional Court, in its assessment of damage to the environment, implements a balance of interests technique or the protection of the environment does not always win in the

\footnotetext{
${ }^{31}$ GAY (L), Les « droits-créances » constitutionnels, collection de droit public comparé et européen, Bruylant 2007.

${ }^{32}$ MATHIEU (B.), « La constitutionnalisation du droit de l'environnement : La Charte adossée à la Constitution française $\gg$, op. cit., p.7.

${ }^{33}$ Cf. MATHIEU (B.), op. cit., p.7.
} 
face of the particular nature of other rights at stake ${ }^{34}$. The Chadian constitutional court can and will not be wrong in adopting this position of the Czech one who used the balance of interest technique, and that will be a risk for human rights to a healthy environment. Constitutionalized in the same way as other fundamental rights but which unfortunately because of balance of interest can see its place relegate to the background. Indeed, in 2000, when the Czech Constitutional Court considered the arguments of an applicant who argued that the Czech law on commercial advertising did not respect the constitutional provisions protecting the right to health and a healthy environment, insofar as it did not limit tobacco advertising only in certain circumstances. The Court, for its part, considered that "this right is an element of the objective and institutional aspect of the right to life, which is a distinct element both of the fundamental rights ${ }^{35}$ of the individual and of the social obligations or objectives assigned to him. State, and by virtue of which the latter may freely choose to act or not to act ". In the end, the law on commercial advertising passed without concern the control of constitutionality, because the Court had considered that the State could not limit the freedom of expression, fundamental right, on the basis of neither the right to health ${ }^{36}$, nor the right to a healthy environment ${ }^{37}$. This example amply demonstrates that this constitutional protection of the environment may be negligible compared to other fundamental rights.

This constitutionalization of a fundamental right to the environment does not benefit from direct justiciability.

\section{$B$ - A relativized protection by an indirect justiciability}

To say that the right to a healthy environment does not benefit from a direct and therefore indirect justiciability signifies the fact that the right to a healthy environment can only be protected through the vector of subjective rights, such as protected in rights catalogs. It is therefore only through an appeal against other individual rights that an application can have the chance of succeeding.

Thus, this justiciability is indirect because of a certain lack of direct effect (1) sometimes requiring recourse to the activation of ordinary remedies (2).

\section{1) Lack of direct effect}

The constitutional norms of Chad that enshrine environmental law would not have direct effect. In order to allow the litigants to activate the ordinary legal means, because being rights-receivables, it is necessary first of all the intervention of the legislator. And if this requires the intervention of the legislator, therefore it cannot as such, be the cause of a direct referral of the judge by the applicants. Therefore, in the absence of specific rules adopted by the legislature that prohibit such behavior or, conversely, force action in a specific direction, it is not sufficient to invoke in the courts an impairment of the quality of its environment. to be able to demand of a third party, who does not commit any fault, a determined behavior $^{38}$. This was the position of the Brussels Court of Appeal of 24 January 1997 when the action was originally brought by residents of the Zaventem airport who criticized the Belgian State and the operators in particular to undermine the quality of their environment. Also, Hatton No. 2 "operates a very clear setback" in terms of protecting the right to a healthy environment. This decline was accentuated by the case Kyrtatos c. Greece of 22 May 2003 which gave the Court the opportunity to clarify that "nothing in the Convention specifically guarantees a general protection of the environment as such" ${ }^{39}$. These different jurisprudential positions can be followed by the Chadian courts, which cannot guarantee the maximum protection of human rights in oil exploitation. It seems to us that we are rather in the presence of an environmental constitutional provision which establishes a "constitutional mandate" 40 for the State and which does not, in itself, entitle the applicants to take legal action against the State. In addition, to allow for some direct effect, the Chadian constitution would provide a clear reference as an example in the Bolivian Constitution, where it is expressly stated that any person individually or collectively, is able to undertake actions to defend the right to the environment and that the mechanism of popular action is possible against any act or omission of the authorities and individuals or collective persons who infringe or threaten to infringe collective rights and interests related to the environment ${ }^{41}$.

Noting the direct effect of recourse to parallel remedies appears as an alternative.

\footnotetext{
${ }^{34}$ On this subject, read the article by BURGORGUE-LARSEN (L), « La protection constitutionnel de l'environnement en droit comparé », Environnement n ${ }^{\circ} 12$, décembre 2012, dossier 30, p.3.

35 This unfortunately allows us to see that there is a hierarchy between fundamental rights and therefore we can notice that not all fundamental rights are equal.

${ }^{36}$ Article 70-D of the Czech Constitution.

${ }^{37}$ Article 18 idem.

${ }^{38}$ Court of Appeal of Brussels, 24 January 1997.

${ }^{39}$ See BURGORGUE-LARSEN (L), « La protection constitutionnelle de l'environnement en droit comparé », op. cit., pp.1-30.

${ }^{40}$ Ibid, p.4.

${ }^{41}$ See article of the Bolivian constitution.
} 


\section{2) Activation of parallel remedies}

In the absence of a direct effect of the right to the environment, in most cases the case law has resorted to other formulas such as the protection of private and family life or the right to life to devote indirectly the justiciability of this right to a healthy environment which is nevertheless constitutionalized. This is for example the case in the European Union, it is only by a dynamic interpretation of these provisions that allowed the European Commission to pronounce, for the first time in 1980, on a case concerning the environment ${ }^{42}$. But it is the Powel and Rayner judgment of February 21, 1990, which is traditionally referred to by the doctrine as the starting point for the work of the Court. This decision raised the problem of noise pollution caused by the operation of airports. The highly anticipated position of the Court, however, was disappointing. Although he felt that the sound of Healthrow airport aircraft "diminishes the quality of privacy and home amenities of both applicants". The fact that the right to one can be retained through other rights may be a risk of departing from this notion. In this area of the right to a healthy environment, it has been noted that the Court makes a group use of the different concepts of Article 8 of the Convention. In particular, the Court found that "serious harm to the environment may affect the well-being of a person and deprive him of the enjoyment of his home in such a way as to harm his private and family life"43. Similarly, it defines the home as "normally the place, the physically determined space or develops the private and family life", the individual entitled "to the respect of his home, conceived not only as the right to a simple physical space but also as the one to the enjoyment, in all tranquility, of the said space "44. In doing so, the European judge, "substitutes for the three rights in question - the right to respect for private life, the right to respect for family life, the right to respect for one's home - one single right, with a heterogeneous content $" 45$.

Lastly, ordinary legal remedies must be used. In fact, when a citizen feels that his right to a healthy environment has been violated thus causing damage to his patrimony, he has the possibility of appealing to the ordinary courts ${ }^{46}$ against the alleged perpetrators of such an act by putting into action the action on the basis of Article 1382 of the former French Civil Code of 1958 in force in Chad on liability for misconduct. Also, criminal courts can be seized by the Ministry of Environment or the Public Prosecutor in case of a criminal offense in the environmental field. The criminal court can also be seized by any citizen who considers himself a victim of a criminal offense in environmental matters. Similarly, any act of the public authorities that causes harm to an individual, the latter could seize the administrative judge to annul the act or receive a fair compensation. Unfortunately in practice these mechanisms are rarely activated ${ }^{47}$.

\section{REFERENCES}

$>\quad$ BIRUKA (I), La protection de la femme et de l'enfant dans les conflits armés en Afrique, L'Harmattan, 2006, p. 27.

$>$ BUGNION $(\mathrm{F})$, « le Comité international de la Croix-Rouge et la protection des victimes de guerre », in Revue Internationale de la Croix-Rouge, $\mathrm{n}^{\circ} 775$, janvier-février 1985, p.5.

> BURGORGUE-LARSEN (L), « La protection constitutionnelle de l'environnement en droit comparé », Environnement et Développement durable, ${ }^{\circ} 12$, décembre 2012, dossier 30, pp.1-30;

$>$ BURGORGUE-LARSEN (L), «La protection constitutionnelle de l'environnement en droit comparé », op.cit., p.2.

> BURGORGUE-LARSEN (L), «La protection constitutionnelle de l'environnement en droit comparé », op. cit., pp.1-30.

$>$ ECHR, decision Arrondelle c. R.U of July 15, 1980, D.R., 19, p. 186

$>$ G., El medio ambiente en la Constitución española de 1978, p. 321, note 7. Voir aussi : GOMES DA SILVA, J. C., Human rights in the portuguese Constitution. Cité par BURGORGUE-LARSEN (L), « La protection constitutionnelle de l'environnement en droit comparé », op. cit., pp.1-30.

$>$ GAY (L), Les « droits-créances » constitutionnels, collection de droit public comparé et européen, Bruylant 2007.

> HAUMONT (F), «Le droit constitutionnel belge à la protection d'un environnement sain. Etat de la Jurisprudence »; Revue juridique de l'environnement, 2005, nº spécial, pp.41-52 Etc.

$>$ IANJATIANA (R.), « La protection constitutionnelle de l'environnement au Madagascar », Revue Juridique de l'Environnement, 2016, vol pp. $\neg 122-139$.

$>$ Larousse 2010 .

DATHIEU (B.), «La constitutionnalisation du droit de l'environnement : La Charte adossée à la Constitution française », Xe Journées juridiques franco-chinoises, Paris 11-19 octobre 2006.

$>$ MATHIEU (B.), « La constitutionnalisation du droit de l'environnement : La Charte adossée à la Constitution française », op. cit., p.7.

${ }^{42}$ ECHR, decision Arrondelle c. R.U of July 15, 1980, D.R., 19, p. 186.

${ }^{43}$ Law Lopez-Ostra c. Spain delivered by the ECHR on 09 December 1994.

${ }^{44}$ See CEDH, Moreno Gomez c. Spain16 November 2004.

${ }^{45}$ Ibidem.

${ }^{46}$ For example, the courts.

${ }^{47}$ ZAKANE (V.), «Problématique de l'effectivité du droit à l'environnement en Afrique : l'exemple du Burkina Faso », in Aspects contemporains du droit de l'environnement en Afrique de l'Ouest et centrale. - GRANIER L. (coord.), UICL, Gland, Suisse, 2008, p.20. Cité par BURGORGUE-LARSEN (L), « La protection constitutionnelle de l'environnement en droit comparé », op. cit., p.5. 
$>$ MORAND-DEVILLER $(\mathrm{J})$, « L'environnement dans les constitutions étrangères », Les Nouveaux Cahiers du Conseil Constitutionnel, 2014/2, n 43 pp.83-95

$>$ PRIEUR (M), "Promesses et réalisations de la Charte de l'environnement », Les Nouveaux Cahiers du Conseil Constitutionnel, 2014/2, n43, pp. 5-24.

$>$ PRIEUR (M.), «La non régression condition du développement durable » in Révue Vraiment durable, 2013/1, p.177.

$>$ RANDRIANANDRASANA (I), «La protection constitutionnelle de l'environnement à Madagascar, Revue juridique de l'environnement, 2016/1, vol.41, pp 122-139;

$>$ United Nations Conference on the Environment held in Stockholm from 5 to 16 June 1972; United Nations Conference on Environment and Light Development in Rio de Janeiro from 3 to 14 June 1992 etc.

$>$ ZAKANE (V.), «Problématique de l'effectivité du droit à l'environnement en Afrique : l'exemple du Burkina Faso », in Aspects contemporains du droit de l'environnement en Afrique de l'Ouest et centrale. - GRANIER L. (coord.), UICL, Gland, Suisse, 2008, p.20. Cité par BURGORGUE-LARSEN (L), « La protection constitutionnelle de l'environnement en droit comparé », op. cit., p.5. 